\title{
Klarifikasi Makna Nilai Personal dalam Pembentukan Moral Pendidikan
}

\author{
Faridatul Munawaroh ${ }^{1}$, Nova Adi Kurniawan ${ }^{2}$ \\ 1 PIAUD, STAI Auliaurrasyidin
}

\begin{abstract}
ABSTRAK
Artikel ini mencoba memberi penjelasan atas makna nilai personal dalam pembentukan moral pendidikan yang menjadi tolak ukur untuk melakukan moral yang baik. Klarifikasi makna nilai adalah penjelasan identitas yang memberikan corak khusus kepada pikiran perasaan maupun perilaku. Klarifikasi nilai berhubungan dengan perkembangan fisik secara normal. Pendidikan dan penilaian disesuaikan dengan perkembangan. Didalam ilmu filsafat manusia, tahap perkembangan akal pikiran terdiri dari tahap teologis, metafisis, positif, dan eksistensi. Eksistensi terdiri dari tahap ekstetis, etis, dan tahap religius. Sementara itu, pembinaan akhlak mulia untuk mencegah merebaknya mental buruk adalah melalui pengembangan moral knowing, moral feeling, moral action.
\end{abstract}

Kata Kunci: Klarifikasi, Nilai, Moral Pendidikan

\begin{abstract}
This article clarifies the meaning of personal values on creating moral education. Meaning clarification of values is a special identity to mind, feeling, and attitudes. Values clarification is in coherence with normal physical development. Education and assessment should touch the stages of the development. The stages of mind development consist of theological, metaphysical, positive, and existence. Existence consist of eclectic, etic, and religious. Meanwhile, fostering moral should develop moral knowing, moral feeling, and moral action.
\end{abstract}

Keywords: Clarification, Values, Moral of Education.

\section{PENDAHULUAN}

Manusia dalam tindakan dan perilaku perbuatan, digerakkan oleh nilai-nilai. Dua tindakan yang sama, tapi berbeda nilai yang dikandungnya, berbeda pula penghargaan terhadap tindakan-tindakan itu. Tiap tindakan yang dilakukan dengan sadar, selalu digerakkan oleh motif dan mengarah kepada tujuan, motif merupakan sebab; tujuan, akibat. Motif mendorong kita untuk bertindak atau melakukan sesuatu. Apa tujuan tindakan itu? Sesuatu yang dikehendaki, yang diperlukan, yang berguna, yang dimaui, yang memuaskan.

Hidup bermakna gerak. Manusia bertindak, berlaku dan berbuat. Di belakang tiap tindakan dan perilaku perbuatan selalu ada motif. Manusia bertindak, 
karena ada sesuatu yang ingin dicapainya. Kepuasan terjadi, kalau sesuatu yang dipandang berharga tercapai. Tiap yang dipandang berharga itu mengandung nilai.

Seperti membunuh seseorang untuk mendapatkan harta atau kedudukannya adalah kejahatan. Membunuh orang dalam membela diri, bukanlah dipandang jahat. Membunuh orang dimedan perang adalah tindakan terpuji. Makin banyak prajurit membunuh musuh dimedan tempur, makin dipuja ia sebagai pemberani. Pembunuh pada peristiwa ketiga dihadiahi bintang pahlawan. Dengan misal tersebut jelaslah betapa tindakan-tindakan yang sama, mengandung nilai yang berbeda(Gazalba, 1981, hal. 40)

Kasus lain yang terdapat pada seorang ibu tega membuang anaknya, karna disebabkan beberapa faktor, seorang laki-laki tega menghabisi istrinya sendiri karena perempuan lain. Pembunuhan atau tindakan tersebut sudah tidak ada nilai yang berhubungan dengan moral kemanusiaan sama sekali. Lantas bagaimana klarifikasi makna nilai dalam moral pendidikan?

\section{Pengertian Klarifikasi Makna Nilai}

Klarifikasi adalah pengertian, penjelasan dan pengembalian kepada hal yang sebenarnya(Yuwono \& Silvita, 2009, hal. 36). Sementara itu, nilai adalah suatu seperangkat keyakinan atau perasaan yang diyakini sebagai suatu identitas yang memberikan corak yang khusus kepada pola pemikiran, perasaan, keterikatan maupun perilaku. Oleh karena itu sistem nilai dapat merupakan standar umum yang diyakini, yang diserap dari keadaan obyektif maupun diangkat dari keyakinan, sentimen (perasaan umum) maupun identitas yang diberikan atau diwahyukan oleh Allah SWT, yang pada gilirannya merupakan sentimen (perasan umum), kejadian umum, identitas umum yang oleh karenanya menjadi syariat umum(Ahmadi \& Salimi, 2004, hal. 50).

Menurut Muhadjir bahwa secara hierarkis nilai dapat dikelompokkan kedalam dua macam, yaitu (1) nilai-nilai ilahiyah, yang terdiri dari nilai ubudiyah dan nilai muamalah; (2) nilai etika insani, yang terdiri dari : nilai rasional, nilai sosial, nilai individual, nilai biofisik, nilai ekonomik, nilai politik, dan nilai estetik(Muhaimin, 2006, hal. 8).

Pengertian tentang apa dan bagaimana sebaiknya akhlak itu harus terwujud. Konsep atau seperangkat pengertian tentang apa dan bagaimana sebaiknya akhlak itu, disusun oleh manusia didalam sistem idenya. Sistem ide ini adalah hasil proses (penjabaran) daripada kaidah-kaidah yang dihayati dan dirumuskan sebelumnya, (norma yang bersifat normatif dan norma yang bersifat deskriptif). Kaidah atau norma yang merupakan ketentuan ini timbul dari satu sistem nilai yang terdapat pada Al-Quran atau Sunnah yang telah dirumuskan melalui wahyu ilahi maupun yang disusun oleh manusia sebagai kesimpulan dari hukum-hukum yang terdapat dalam alam semesta yang diciptakan Allah SWT.

Setelah pola perilaku terbentuk maka sebagai kelanjutannya akan lahir hasilhasil dari pola perilaku tersebut yang berbentuk material (artifacts) maupun non- 
material (konsepsi, ide). Jadi akhlak yang baik itu (akhlakul karimah) ialah pola perilaku yang dilandaskan pada manifestasi nilai-nilai iman, Islam dan Ihsan.

Kalau nilai merupakan keyakinan, sentimen dan atau identitas yang bersifat umum atau strategis, maka penjabarannya dalam bentuk formula, peraturan, atau ketentuan pelaksanaanya disebut norma. Dengan kata lain bahwa norma merupakan penjabaran dari nilai sesuai dengan sifat tata nilai. Tata norma ada yang bersifat standar atau ilahi dan karenanya normatif ada yang bersifat kekinian atau berlaku sekarang juga bersifat deskriptif artinya sesuatu norma yang dirumuskan berdasarkan kenyataan yang berlaku.

\section{Sumber nilai dan norma}

Sesuai dengan penyataan diatas di atas, maka sumber nilai dan norma dapat disimpulkan nilai yang Ilahi (Alquran dan Sunah) dan nilai yang mondial (duniawi) ra'yu (pikiran), adat istiadat dan kenyataan alam. Maka bagi umat Islam sumber nilai yang tidak berasal dari Al-Quran dan Sunnah hanya digunakan sepanjang tidak menyimpang atau yang menunjang sistem nilai yang bersumber kepada Al-Quran dan Sunnah, Firman Allah dalam Q.S Al-An'am: 153(Ahmadi \& Salimi, 2004, hal. 203).

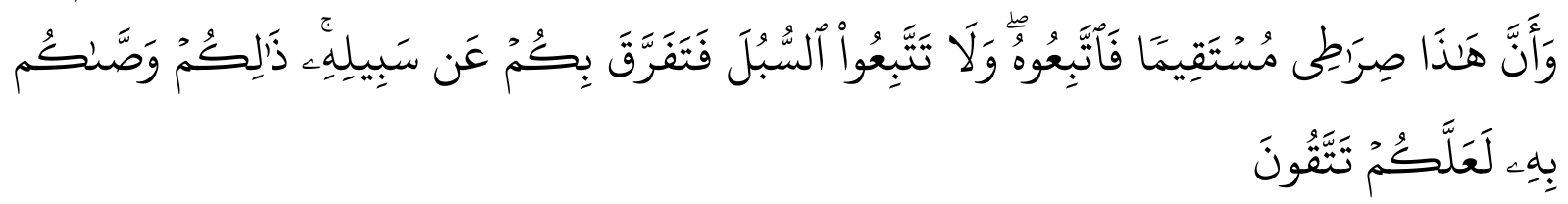

Artinya:Dan bahwa (yang kami perintahkan ini) adalah jalanKu yang lurus, Maka ikutilah Dia, dan janganlah kamu mengikuti jalan-jalan (yang lain), Karena jalan-jalan itu mencerai beraikan kamu dari jalannya. yang demikian itu diperintahkan Allah agar kamu bertakwa. (Q.S Al-An'am : 153).

\section{Moral dalam proses pendidikan}

Moralitas adalah lambang humanitas manusia, karena memang dia diciptakan untuk itu. Potensi psikis berupa akal, hasrat, kemauan, keinginan, dan perasaan mesti diarahkan untuk mampu berimajinasi, berkreatif dan membuat perubahan-perubahan dalam kehidupannya yang berdimensikan nilai-nilai moral tertinggi.

Dalam islam, apa yang menjadi tujuan penciptaan manusia, maka itu pulalah yang menjadi cita-cita atau tujuan pendidikan. Mengingat tujuan penciptaan manusia adalah untuk moral, maka tentu penyempurnaan moralitas adalah juga menjadi tujuan dan sekaligus hak yang esensial bagi pendidikan itu sendiri (Muhmidayeli, 2007, hal. 74).

Contoh Imam Al-Ghazali dengan ucapannya "seorang guru hendaklah membatasi dirinya dalam bicara dengan anak-anak sesuai dengan daya pengertiannya jangan diberikan kepada sesuatu yang tidak dapat ditangkap oleh akalnya karena akibatnya ia akan lari dari pelajaran atau akalnya memberontak terhadap pelajaran tersebut. Isyarat ini adalah sesuai dengan tuntunan Nabi Muhammad SAW yang artinya: "Kami para Nabi, diperintahkan untuk menempatkan 
seseorang pada posisinya, berbicara dengan seseorang sesuai dengan akalnya".Perkembangan moral seseorang seiring pula dengan perkembangan pisik dan fisikisnya, dibawah ini akan diuraikan bagaimana perkembangan moral seseorang pada tahap perkembangan tertentu yang didahului dengan analisis konsep nilai dalam filsafat moral.

\section{METODE PENELITIAN}

Pendekatan yang digunakan dalam artikel ini adalah pendekatan kepustakaan (library research) dengan mengkaji berbagai literature yang relevan dengan topik kajian. Berangkat dari permasalahan yang ada kemudian dikaji menggunakan teori dari berbagai sumber kemudian Hasil dari kajian tersebut dianalisa sedemikian rupa dengan menggunakan informasi-informasi yang sesuai dengan topik kajian. Kemudian, hasil tersebut dibahas secara deskriptif.

\section{HASIL DAN PEMBAHASAN}

Kajian tentang nilai (value) dalam filsafat moral dapat disebut sebagai kajian yang amat penting. Hal ini tidak saja posisinya sebagai problema awal dalam kajian ini, tetapi lebih dari itu, yaitu sebagai kajian yang menyentuh persoalan substansial dalam etika atau filsafat moral. Kajian dalam persoalan ini biasanya mempertanyakan apakah yang "baik" dan "tidak baik" atau bagaimana seseorang "mesti" berbuat "baik" serta tujuan yang bernilai. Khusus dengan karakteristik yang terakhir ini menyentuh pula mengenai apa dasar yang menjadi pembenaran suatu keputusan moral, ketika disebut "baik" atau "tidak baik" dengan kata lain kajian tentang nilai dalam filsafat moral selain bermuatan normatif, juga metaetika.

Setidaknya ada dua aliran dalam kajian nilai (values) yakni naturalisme dan nonnaturalisme. Bagi naturalisme nilai (values) adalah sejumlah fakta, oleh karena itu, setiap keputusan nilai dapat diuji secara empirik. Sementara bagi non-naturalisme, nilai (values) itu tidak sama dengan fakta, artinya fakta dan nilai merupakan jenis yang terpisah dan secara absolut tidak tereduksi satu dengan yang lain. Oleh karena itu, nilai (values) tidak dapat diuji secara empirik.

Mengingat nilai itu fakta bagi kelompok naturalisme, maka sifat perilaku yang baik seperti jujur, adil, dermawan dan lainnya atau kebalikannya merupakan indikator untuk memberi seseorang itu berperilaku baik atau tidak baik. Selain bentuk pengujian seperti ini, konsekuensi dari setiap perbuatan adalah juga merupakan indikator untuk menetapkan sesuatu perbuatan seseorang itu baik, atau tidak baik. Dengan demikian dapat dikatakan bahwa keputusan nilai pada naturalisme bersifat ungkapan faktual, sehingga dapat diuji secara empirik.

Berbeda dengan kelompok diatas, mengingat bagi non-naturalistik nilai itu bukan fakta, tetapi bersifat normatif dalam memberitahukan sesuatu itu apakah baik atau buruk, benar atau salah, maka keputusan nilai pada kelompok ini tidak dapat diketahui melalui uji empirik, akan tetapi hanya dapat diketahui melalui apa yang disebutnya dengan intuisi moral yang telah dimiliki manusia, yaitu kesadaran 
langsung adanya nilai murni seperti benar atau salah dalam setiap perilaku, objek atau seseorang. Deontologis dan prima facies duties merupakan diantara kelompok aliran non-naturalistik, sementara teologis dengan utilitarianisme termasuk naturalistik.

Bagi deontologis, suatu tindakan itu benar karena perbuatan itu sendiri, sedangkan bagi utilitarianisme tindakan itu benar karena konsekuensi tindakan itu, sehingga dapat dikatakan pula bahwa bila pada deontologis nilai moral dari suatu tindakan itu bersifat intrinsik, maka utilitarianisme bersifat ekstrinsik, artinya nilai moralnya tergantung pada konsekuensi perbuatan tersebut. Dengan demikian dikatakan pula, bahwa nilai enstrinsik suatu perbuatan sama sekali tergantung pada nilai instrinsik dari pengaruhnya. Sebaliknya bagi deontologis, nilai moral suatu perbuatan adalah intrinsik, artinya suatu perbuatan dapat diketahui baiknya tanpa memperhatikan apa bentuk konsekuensi dan relasinya terhadap yang lain(Amril, 2002, hal. 34).

\section{a. Tahap Perkembangan Moral Prososial}

\begin{tabular}{|l|l|l|}
\hline Tahap & Perkiraan Umur & Respons Umum \\
\hline Hedonistik & $\begin{array}{l}\text { Prasekolah, awal } \\
\text { sekolah dasar }\end{array}$ & $\begin{array}{l}\text { Perhatian untuk kebutuhan seseorang. } \\
\text { Memberi bantuan dilakukan jika } \\
\text { menguntungkan diri sendiri. Misalnya } \\
\text { "saya tidak bisa membantu karena akan } \\
\text { kehilangan pesta" }\end{array}$ \\
\hline $\begin{array}{l}\text { Berorientasi } \\
\text { kebutuhan }\end{array}$ & $\begin{array}{l}\text { Sekolah dasar dan } \\
\text { sedikit prasekolahan }\end{array}$ & $\begin{array}{l}\text { Kebutuhan seseorang merupakan } \\
\text { legitimasi untuk membantu, tetapi } \\
\text { hanya sedikit bukti simpati atau rasa } \\
\text { bersalah jika gagal membantu. Misalnya } \\
\text { "saya akan membantu karena dia } \\
\text { membutuhkan pertolongan" }\end{array}$ \\
\hline $\begin{array}{l}\text { Berorientasi } \\
\text { stereotipik } \\
\text { dan } \\
\text { persetujuan }\end{array}$ & $\begin{array}{l}\text { Sekolah dasar dan } \\
\text { tidak beberapa } \\
\text { sekolah menengah }\end{array}$ & $\begin{array}{l}\text { Kepentingan untuk mendapatkan } \\
\text { persetujuan atau citra stereotipik } \\
\text { tentang baik dan buruk sangat } \\
\text { memengaruhi berpikir seseorang, } \\
\text { misalnya "ibu akan memeluk saya } \\
\text { karena membantu" }\end{array}$ \\
\hline $\begin{array}{l}\text { Orientasi } \\
\text { empatik }\end{array}$ & $\begin{array}{l}\text { Akhir sekolah dasar } \\
\text { dan sekolah } \\
\text { menengah }\end{array}$ & $\begin{array}{l}\text { Penilaian meliputi bukti dari perasaan } \\
\text { simpatik, acuan yang samar kadang } \\
\text { terbentuk terhadap tugas-tugas dan } \\
\text { nilai-nilai. Misalnya "saya merasa } \\
\text { beruntung dapat membantu, karena ia } \\
\text { terlihat menderita" }\end{array}$ \\
\hline $\begin{array}{l}\text { Orientasi } \\
\text { nilai yang } \\
\text { terinternalis }\end{array}$ & $\begin{array}{l}\text { Minoritas kecil } \\
\text { sekolah menengah } \\
\text { dan tidak ada }\end{array}$ & $\begin{array}{l}\text { Justifikasi untuk membantu (atau tidak } \\
\text { membantu) didasarkan pada nilai-nilai, } \\
\text { norma, kepercayaan, dan tanggung }\end{array}$ \\
\hline
\end{tabular}




\begin{tabular}{|l|l|l|}
\hline asi & sekolah dasar & jawab, melanggar prinsip ini akan \\
& & mengurangi kehormatan diri. Misalnya \\
& "saya tidak mau menjadi donator \\
& karena yayasan banyak membuang \\
& uang untuk mengumpulkan dana dan \\
& hanya sedikit orang yang seharusnya \\
& menerima yang mendapatkan bantuan \\
& keuangan" \\
\hline
\end{tabular}

\section{b. Kontrol Perilaku Agresivitas}

Perilaku agresif adalah segala bentuk perilaku yang disengaja dibuat untuk menyakiti atau melukai makhluk hidup yang memiliki motivasi untuk menghindarinya. Agresivitas bukan merupakan konsekuensi perilaku. Namun, suatu perilaku merupakan agresivitas jika terdapat niat untuk menyakiti orang lain, misalnya tendangan keras yang meleset dan lain-lain. Sebaliknya jika tidak terdapat niat, maka hal itu dapat dianggap bukan agresivitas, misalnya kecelakaan lalu lintas, dan lain-lain.

Islam, pada intinya, merupakan agama perdamaian yang aturanaturannya menjadi rahmat bagi semesta alam. Islam menyuruh umatnya untuk berlaku lemah lembut dan tidak menyakiti orang lain. Bahkan termasuk dalam menjaga kata-kata, seperti ayat berikut ini.

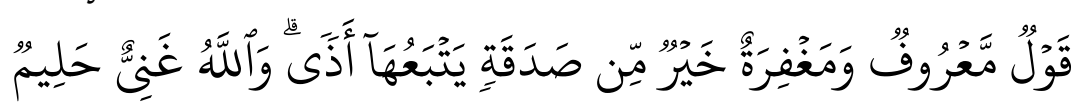

Artinya: Perkataan yang baik dan pemberian maaf lebih baik dari sedekah yang diiringi dengan sesuatu yang menyakitkan (perasaan penerima) Allah Maha kaya lagi maha Penyantun. (QS. Al-Baqarah: 263).

Firman Allah di dalam QS.Al-Hujarat:11 mengatakan:

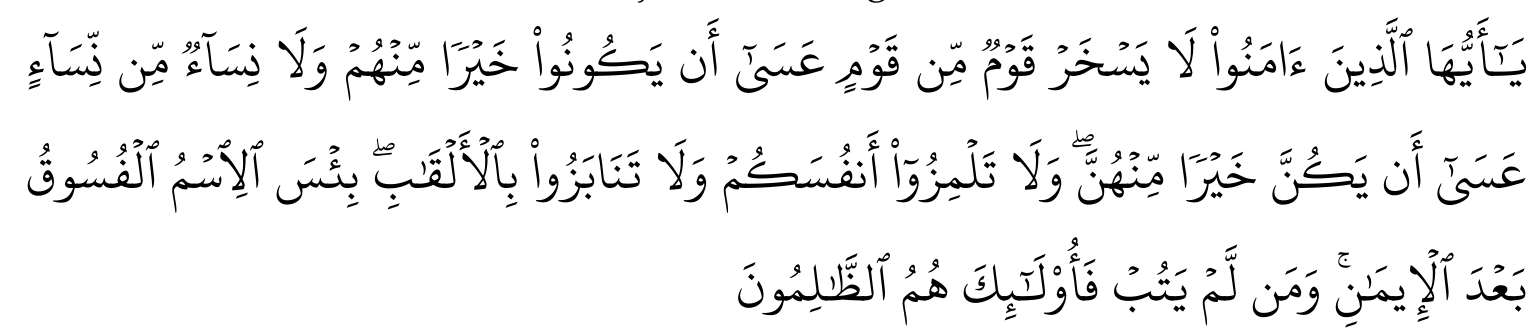

Artinya: Hai orang-orang yang beriman, janganlah suatu kaum mengolok-olokkan kaum yang lain, boleh jadi mereka (yang diolok-olokkan) lebih baik dari mereka (yang mengolok-olokkan), dan jangan pula wanita-wanita mengolok-olokkan wanita-wanita yang lain, boleh jadi wanita (yang diolok-olokkan) lebih baik dari wanita (yang mengolokolokkan) dan janganlah kamu mencela diri sendiri. Dan janganlah kamu memanggil dengan gelar-gelar yang buruk, seburuk-buruknya panggilan ialah (panggilan) yang buruk sesuadah iman dan barang siapa yang tidak bertobat, maka mereka itulah orangorang yang zalim (QS. Al-Hujarat:11). 
Orang yang mampu mengontrol diri untuk tidak menyakiti orang lain, meskipun dalam keadaan marah merupakan orang yang perkasa dalam pandangan Islam.

"Dari Abdullah bin Mas'ud bahwa Rasulullah SAW, bertanya kepada para sahabatnya; "Siapa yang kalian anggap sebagai orang yang perkasa diantara kalian?" para sahabat berkata: "Orang yang tidak pernah dibanting oleh orang-orang." Rasululah bersabda "Tidak akan tetapi yang disebut orang perkasa adalah orang yang mampu menguasai dirinya ketika sedang marah". (HR. Muslim dan Abu Dawud).

Tindakan agresif sering dibagi atas dua kategori, yaitu Agresif permusuhan (Hostile aggression) dan agresif instrumental (Instrumental aggression). Agresif permusuhan merupakan tindakan agresif dengan tujuan utama untuk menyakiti atau melukai korban. Sementara agresif instrumental merupakan perilaku yang memiliki tujuan utama untuk mendapatkan akses pada objek, ruang atau hak-hak yang dimiliki. Namun, tindakan yang sama dapat digolongkan baik kedalam permusuhan atau tergantung pada situasi. Jika seorang anak laki-laki mengganggu dan mengejek adik perempuannya hingga menangis, maka ia dikatakan melakukan agresif permusuhan. Tetapi perilaku yang sama juga dapat dikatakan agresif instrumental jika anak laki-laki tersebut juga merusak mainan yang sedang dipergunakan adik perempuannya(Hasan, 2006).

\section{c. Perkembangan Moral}

Menurut Robert J. Havinghust, moral yang bersumber dari adanya suatu tata nilai adalah "a value is an obyect estate or affair wich is desired" (tata nilai adalah suatu obyek rohani atas suatu keadaan yang diinginkan). Maka kondisi atau potensi internal kajiwaan seseorang untuk dapat melakukan hal-hal yang baik, sesuai dengan nilai-nilai (value) yang diinginkan itu disebutnya sebagai moral. Dengan demikian perkembangan moral seseorang itu berkaitan erat dengan perkembangan sosial anak, disamping pengaruh kuat dari perkembangan pikiran, perasaan serta kemauan atas hasil tanggapan dari anak. Bagi seorang anak pengembangan moral itu akan dikembangkan melalui pemenuhan kebutuhan jasmaniah (dorongan nafsu fisiologis). Untuk selanjutnya dipolakan melalui pengalaman dalam lingkungan keluarga, sesuai dengan nilai-nilai yang diberlakukannya. Maka disinilah sebenarnya letak peranan utama bagi orangorang yang paling dekat atau akrab dengan anak (terutama ibu) dalam memberikan dasar-dasar pola perkembangan moral anak berikutnya.

Ahmadi \& Salimi (2004, hal. 48) menjelaskan perkembangan moral anak yang disesuaikan dengan value/tata nilai sebagai berikut:

$1 ; 0-4 ; 0=$ Ukuran baik dan buruk bagi seorang anak itu tergantung dari apa yang dikatakan oleh orang tua. Walaupun anak saat itu belum tahu benar hakikat atau perbedaan antara yang baik dan yang buruk itu. Sebab saat itu anak belum juga mampu menguasai dirinya sendiri. 
4;0-8;0 = Ukuran nilai bagi seorang anak adalah dari yang lahir (realita). Anak belum dapat menafsirkan hal-halnya yang tersirat dari sebuah perbuatan, antara perbuatan yang disengaja atau tidak, anak belum mengetahui, yang ia menilai hanyalah kenyataannya. (dari sebab perbuatan tadi). Contoh, Anak akan tetap menilai salah terhadap orang yang memecahkan gelas 20 buah (satu kodi) walaupun tidak disengaja. Tetapi anak tadi akan memaklumi, terhadap seorang yang hanya memecahkan 1 (satu) gelas, walaupun disengaja.

8;0-13;0 = Anak sudah dapat mengenal ukuran baik, buruk secara batin (tak nyata) meskipun masih terbatas, yaitu anak sudah dapat menghargai pendapat atau alasan dari perbuatan orang lain. Anak mulai dapat menghormati terhadap orang lain yang patuh, taat, atau sebaliknya.

13;0 - 19;0 = Seorang anak sudah mulai sadar betul tentang tata nilai kesusilaan (value). Anak akan patuh atau melanggar berdasarkan kefahamannya terhadap konsep tata nilai yang diterima. Pada saat ini anak benar-benar berada pada kondisi dapat mengendalikan dirinya sendiri.

\section{d. Pendidikan anak disesuaikan dengan umurnya.}

Disini akan dijelaskan pendidikan anak mulai dari 3 sampai 6 thn, 6 sampai 13 tahun, dan 20 tahun keatas. Pendidikan anak mulai 3-6 tahun.

1) Umur ini anak sudah dapat diberi kebiasaan-kebiasaan, maka berikanlah kebiasaan-kebiasaan yang baik, seperti: meletakkan sepatu ditempatnya, belajar teratur kalau sudah masuk sekolah, mencuci kaki sebelum tidur dan lain-lain.

2) Bahasa yang halus dan sopan santun harus dilatih.

3) Dilatih menghormati orang tuanya dan orang yang lebih tua.

4) Anak ini sudah dapat menerima nasehat-nasehat.

5) Kurang lebih 5 tahun timbullah masa protes 1 atau masa "Kemratu-ratu". Waktu ini anak nampak nakal sekali selalu menentang dan ingin menang sendiri. Sebetulnya anak ini ingin mempraktekkan bahwa dia mempunyai kemauan. Perkembangan ini adalah normal maka tak perlu dirisaukan oleh para pendidik atau orang tua. Tetapi pendidik wajib memberi pengertianpengertian yang baik kepada anak didiknya, nanti kalau anak sudah mulai masuk sekolah dan telah puas mempraktekkan kemauannya akan berhenti sendiri.

6) Tak perlu anak banyak ditolong, misalnya waktu belajar berjalan dan lainlain, biarkan kalau dia jatuh, dia akan belajar memecahkan problemnya sendiri.

7) Dia makin membutuhkan teman-teman diluar keluarganya, tak puas kalau teman-teman didalam keluarga. Biasanya lalu bermain-main dengan tetangganya dan teman sekolahnya. 
8) Harus disadari oleh orang tua bahwa tak ada gunanya cepat-cepat memasukkan anaknya ke sekolah sebelum umur. Untuk masuk sekolah taman kanak-kanak jangan sampai kurang dari umur 5 tahun. Untuk SD jangan sampai kurang dari 6 tahun, kecuali kalau memang anak itu sudah dengan kemauan sendiri dan ternyata memang cukup cerdas, jadi jangan dipaksapaksa sebelum waktunya, karena orang tuanya ingin lekas-lekas anaknya masuk sekolah.

9) Masa peka yang dikatakan oleh montessori ialah suatu masa dimana anak itu sangat mudah mempelajari hal sesuatu, maka hal ini harus kita ingat juga, tak usah kita terburu-buru memasukkan sekolah kalau belum masanya, hal ini akan merugikan perkembangan anak, anak akan merasa tertekan dan merasa rendah diri.

10) Anak kelas I S.D biasanya mengalami kesukaran didalam belajar membaca permulaan pada kwartal I, maka harus mendapatkan bantuan belajar dirumah oleh orang tuanya, memang orang tua wajib memberikan bimbingan belajar anaknya dirumah, tetapi harus diingat bahwa dalam belajar anak jangan dipaksa-paksa, apalagi dibentak-bentak kalau salah mengerjakan sesuatu, dengan demikian anak akan jera dan malas belajar. Menginsafkan anak untuk belajar inilah yang penting.

11) Anak harus dibiasakan menolong siapa saja yang membutuhkan pertolongan, hal ini harus dimulai sejak kecil, anak harus dibiasakan menolong orang tuanya dirumah.

12) Makan bersama seluruh keluarga adalah sangat baik, pertama belajar makan sopan, kedua menanamkan perasaan bersatu antara keluarga. Berilah pelajaran untuk makan bersama kepada anak seawal mungkin.

13) Umur \pm 3 tahun anak belum dapat membedakan antara khayal dan nyata, sering anak ini berkata dusta, tetapi maksudnya tidak untuk menipu bahkan menurut anak masuk akal, maka supaya diketahui oleh para pendidik, nanti kira-kira umur 9-10 tahun akan hilang.

14) Anak ini suka menirukan kesibukan di sekitar, meskipun kadang-kadang kenyataannya adalah mengganggu orang tuanya, tetapi maksudnya untuk bermain-main.

15) Anak ini sering menanyakan hal sesuatu yang dia ingin tahu, jangan anak dibentak hingga takut untuk bertanya selanjutnya, hal semacam ini akan merugikan perkembangan jiwa.

Pendidikan anak umur 6 tahun sampai 13 tahun diantaranya :

1) Anak pada umur ini sudah dapat diberikan pendidikan tentang "sek" oleh orang tuanya sendiri, tetapi harus disesuaikan dengan umur anak, anak tak perlu dibohongi tentang sek ini. Jawablah terus terang apabila dia bertanya. Pendidikan soal sek bukan penerangan soal sek, anak membutuhkan 
pendidikan sek ini dari pada anak harus mencari sendiri yang sumbernya mungkin tak dapat dipertanggung jawabkan.

2) Anak pada umur ini selalu aktif tidak pernah diam, kecuali kalau anak sedang sakit, mereka senang kalau kelompoknya lebih unggul dari kelompok yang lain, mereka suka bersaing tetapi juga suka bekerja sama.

3) Harus diperhatikan mengenai pendidikan agama pada anak ini, tetapi tak perlu dipaksa-paksa, berilah kesadaran beragama, berilah contoh-contohnya yang konkrit. Pendidikan agama ini penting sekali untuk membantu terbentuknya watak daripada anak dengan baik.

4) Anak wanita masih ingin disayangi dari pendidiknya. Umur \pm 9 tahun merasa berbeda dengan jenis yang lain, dan sudah ingin mendapat perhatian dari jenis yang lain, tetapi biasanya perasaan ini kalah dengan aktivitas-aktivitas yang lain.

Pendidikan anak umur 13 tahun sampai 20 tahun diantaranya :

1) Masa ini merupakan suatu masa yang istimewa, masa ini juga disebut masa negatif, sturm und drang ; masa pubertas, masa pertentangan, dan lain-lain

2) Masa ini merupakan masa yang penuh dengan pengalaman-pengalaman

3) Anak harus diinsyafkan akan perlunya belajar, sebab anak ini sering keluar rumah karena organisasi-organisasi yang dimasuki membutuhkan perhatian juga

4) Masa puber seolah-olah merupakan perjalanan menuju kedewasaan, banyak pengalaman-pengalaman pada masa kini

5) Anak pada waktu ini betul-betul membutuhkan bimbingan karena mungkin mereka akan terjerumus kalau kurang mendapatkan perhatian dari pendidiknya.

6) Pertolongan kepada anak perlu juga asal disesuaikan dengan umurnya, sebetulnya anak didik puber ini memerlukan orang yang dapat membantu mengatasi kesukaran-kesukaran mereka, mereka membutuhkan bimbingan dari pada pendidik yang sungguh-sungguh mengerti akan kehidupan anak puber ini, kewibawaan merupakan alat pendidikan yang sangat berharga.

Pendidikan anak dewasa antara umur 20 tahun ke atas diantaranya :

1) Masa ini merupakan masa yang tenang. Mereka sudah menyadari bahwa perasaan yang kuat pada masa puber tak perlu diterus-teruskan. Anak sudah mempunyai tanggung jawab yang besar, mereka sudah memikirkan dengan ratio, tak lagi oleh perasaannya, mereka sadar bahwa perasaan itu hanya bagian dari seluruh hidupnya, maka seorang dewasa pandai mengendalikan hidupnya, mereka mulai sadar bahwa nasehat dari pendidikannya memang perlu 
2) Para pendidik yang menghadapi anak didik dewasa, harus mengetahui ilmu jiwa anak didik dewasa, pendidik hanyalah sebagai perantara(Barnadib, 1982, hal. 102).

3) Anak dewasa sudah banyak pengalaman. Sukses atau tidaknya anak didik dewasa tergantung kepada kesempurnaan dan effisiency pendidikan sebelumnya.

Menurut Zainal Abidin dalam bukunya Filsafat Manusia menjelaskan tiga tahap akal pikiran :

\section{1) Tahap Teologis}

Tahap ini terdapat beberapa bentuk atau cara berfikir, bentuk pertama adalah Fetyisme dan Animisme (yang menyakini semua memiliki roh/percaya kepada roh) kemudian terdapat cara berfikir yang lebih maju yang sudah mulai mengatakan, mengelompokkan semua benda dan kejadian kedalam konsep yang lebih umum, pengelompokkan itu didasarkan pada kesamaan diantara mereka, Cara berfikir lebih maju lagi adalah poloteisme, cara berpikir ini tidak lagi mengakuinya banyak (dewa)dari benda-benda dan kejadian, tetapi hanya mengakui hanya satu roh saja.

\section{2) Tahap Metafisis}

Manusia mulai mengadakan perombakan cara berfikir lama yang dianggap tidak lagi sanggup memenuhi keinginan manusia. Manusia pada tahap ini berusaha keras untuk mencari hakikat atau esensi dari segala sesuatu. Mereka tidak lagi puas dengan pengertian-pengertian umum, tanpa dilandasi oleh pemikiran dan argumentasi-argumentasi yang logis.

\section{3) Tahap Positif}

Pada tahap positif, gejala dan kejadian alam tidak lagi dijelaskan secara apriori melainkan berdasar pada observasi, eksperimen dan komparasi yang ketat dan lebih teliti. Gejala dan kejadian harus dibersihkan dari muatan teologis dan metafisika(Abidin, 2000, hal. 131-133).

Tiga tahap esistensi manusia :

(a) Tahap Estetis adalah dimana orientasi hidup manusia sepenuhnya diarahkan untuk mendapatkan kesenangan. Pada tahap ini manusia dikuasai oleh naluri seksual (libido) oleh prinsip-prinsip kesenangan yang hendomistik dan biasanya bertindak menurut suasana hati (mood). Manusia estetis pun adalah manusia yang hidup tanpa jiwa ia tidak mempunyai akar dan isi didalam jiwanya. Kemauannya adalah mengikat diri pada kecenderunan masyarakat dan zamannya. Manusia estetis adalah manusia yang pada akhirnya hidupnya hampir tidak lagi bisa menentukan pilihan, karena semakin banyak alternatif yang ditawarkan masyarakat dan zamannya. Jalan keluarnya hanya ada dua : bunuh diri 
(atau bisa juga lari dalam kegilaan) atau masuk dalam tingkat hidupnya yang lebih tinggi yakni tingkat etis.

(b) Tahap Etis berarti yang semula estetis menjadi etis. Ada semacam pertobatan disini, dimana individu mulai menerima kebaikan-kebaikan moral dan memilih untuk mengikatkan diri kepadanya. Prinsip kesenangan (hendonisme) dibuang jauh-jauh dan sekarang ia menerima dan menghargai nilai-nilai kemanusiaan yang bersifat universal. Sudah mulai ada pilihan dalam menjalankan kehidupan berdasarkan nilai-nilai kemanusiaan yang dipilihnya secara bebas.

(c) Tahap Religius

Keotentikan manusia sebagai subjektivita "Aku" meleburkan diri dalam realita tuhan jauh lebih sulit dari pada lompatan tahap estetis ketahap etis, maka secara rasional kita bisa mempertimbangkan segala konsekuensi yang mungkin akan kita hadapi, sedangkan lompatan dari tahap etis ketahap religius nyaris tanpa pertimbangan rasional, tidak dibutuhkan alasan atau pertimbangan rasional dan ilmiah disini yang diperlukan adalah keyakinan subjektif yang berdasarkan kepada iman. (Abidin, 2000, hal. 150-151).

\section{SIMPULAN}

Dari uraian diatas dapat disimpulkan bahwa Klarifikasi makna nilai adalah penjelasan dan pengembalian kepada makna yang sebenarnya atau yang sesungguhnya, sebagai sesuatu identitas yang memberikan corak yang khusus kepada pikiran perasaan maupun perilaku. Klarifikasi nilai sangat erat hubungannya dengan perkembangan fisik atau umurnya secara normal.

Didalam ilmu filsafat manusia tahap perkembangan akal pikiran manusia terdiri dari tahap teologis, tahap metafisis dan tahap positif, tahap eksistensi manusia terdiri dari tahap ekstetis, tahap etis, tahap religius.

\section{DAFTAR PUSTAKA}

Abidin, Z. (2000). Filsafat Manusia. Bandung: PT. Remaja Rosda Karya.

Ahmadi, A., \& Salimi, N. (2004). MKDU Dasar-dasar Pendidikan Agama Islam. Jakarta: Bumi Aksara.

Ahmadi, A., \& Sholeh, M. (1991). Psikologi Perkembangan. Jakarta: PT. Rineka Cipta.

Amril, M. (2002). Etika Islam. Yogyakarta: LSFK2P dan Pustaka Pelajar.

Barnadib, S. I. (1982). Pengantar Ilmu Mendidik Anak-anak. Yogyakarta: Institute Press, IKIP Yogyakarta.

Gazalba, S. (1981). Sistematika Filsafat. Jakarta: Bulan Bintang.

Hasan, A. B. (2006). Psikologi Perkembangan Islam. Jakarta: PT. Raja Grafindo Persada.

Muhaimin. (2006). Nuansa Baru Pendidikan Islam. Jakarta: Grafindo.

Muhmidayeli. (2007). Teori-teori Sumber Daya Manusia. Pekanbaru: UIN Suska Riau.

Yuwono, T., \& Silvita, I. S. (2009). Kamus Lengkap Bahasa Indonesia (Edisi terbaru). Surabaya: Arikola. 